\title{
Social (Political and Economical) Essence of Globalism and Its Existential Manifistations
}

\author{
Fanil Fagimovich Serebryakov ${ }^{1} \&$ Anton Sergeevich Krasnov ${ }^{1}$ \\ ${ }^{1}$ Kazan Federal University, Russia \\ Correspondence: Fanil Fagimovich Serebryakov, Kazan Federal University Russia. E-mail: \\ fanserebr@yandex.ru; anton-krasnov1987@yandex.ru
}

Received: June 9, 2019

doi:10.5539/jpl.v12n5p156
Accepted: August 25, $2019 \quad$ Online Published: September 3, 2019

URL: https://doi.org/10.5539/jpl.v12n5p156

\begin{abstract}
The paper considers globalism as viewed from ontological theory and its social manifestations primarily in respect of the aspect of "a person in a situation of globalism". The latter can be described in sociological or psychological terms, but in the work this aspect is understood in the socio-philosophical sense, that is, when it undergoes an analysis of the transformation of a person as a cultural-historical type.

It is noted that in "globalism" we can distinguish at least two qualities, internal and external, - one, internal, related to the political and economic (social) content of this concept, that is, with the essence of globalism, the other, external, expresses a set of phenomena and processes of external, "visible", measured, presented in the forms of economic and social activity, mediated by the introduction of high technologies, means of communication, etc. The internal (socio-economic) basis of modern globalism is made up, therefore, is predetermined and mediated by other, subordinate, its aspects, the capitalist mode of production and the imperialistic nature of the claims of capitalism. A person loses the "former entirety of his nature", becomes a function of a thing, an element in the functional interaction of things, from whom it is required to develop one of his side natures (employee), his needs (at other people's expense) to hypertrophied dimensions. It is shown how this is manifested in the field of education reform.
\end{abstract}

The conclusion is drawn: the cultivation of the supersubstantial spiritual wealth of the masses is not the goal of any of the areas of immaterial activity in the era of globalism..

Keywords: globalism, capitalism, essence, open economy, global problems, social relations, people, functionalism, education

\section{Introduction}

The language is given to the diplomat in order to hide his thoughts; it is given to the poet to express his feelings; to the prophet - to deliver the innermost, and to the scientist - to communicate the truth. And it is given only to the ideologist for all this together, even if he does not set himself the goal to find out the truth as a scientist does, and he does not at all strive to make the secret manifest as the prophet does. Because the ideologist sincerely considers himself to be the one and the other, and the third in one person, replacing the objective reality with subjective mythologems.

The same, however, he essentially appears to be - a learned spokesman for the interests of his class (stratum, "nation", estate), he poetizes these completely non-poetic "matters", because he can think and talk about them not otherwise by "an elevated style". But he does not dissemble: they really seem to be natural, universal and true to him. Such are the intricacy and the "secret" of ideological consciousness, unknown to this prophet of a profane deity - Interest, put, however, into the sacred garments of "high values". But more often than not, of all his personalities, he has to act as a diplomat, behind the cobwebs of words and concepts inspiringly concealing the real essence of things. Inferences and justifications in this case are substituted for sophisms, concepts and scientifically neat descriptions - for euphemisms or the concepts of "vanka-vstanka", taken in the most general form (folk character, spirituality, democracy, freedom, independent, etc.).

One of these products of ideological awareness is the concept of globalism, which is nothing more than a deception concept. Euphemism meant to mitigate "rudeness", "vulgarity" and "oversimplification" that are "heard" in another concept-image - "capitalism-imperialism", which actually expresses the essence of modern globalism. A 
notion from the category, as is customary to be expressed in such cases (however, hardly without a fair amount of hypocrisy), politically correct, not wounding the ears with its being direct. After all, it's not the same thing whether to say "coward" or "cautious", "unprincipled" or "modern", "obsequious" or "flexible", "principled" or "hidebound", "narrow-minded", "conservative"

\section{Methods}

The analysis of the phenomenon under consideration - globalism - in accordance with the research goal, clearly implied in the title of the work, is possible when relying on the cognitive potential of the dialectic of the essence and phenomenon, one and many, form and content, abstract and concrete. In the article we tried to consistently adhere to this. Historical and comparative-historical methods without which it is impossible to trace the genesis and formation of globalism, difficult to distinguish and identify them in the totality of historical social and social phenomena are used, and the method of ascension from abstract to concrete is applied, which allows obtaining not only knowledge about globalism and the essence of globalism, but, if possible, its "portrait" as a multidimensional and multilevel complex phenomenon.

\section{Results and Discussion}

What is usually meant by globalism? A certain inevitable and organic result of scientific, technical and economic progress, a logical expression of the needs of human development, etc., consisting in the transition from closed national economies to "open economy", "or global", as one of the works of Western sociologists says. Therefore, this concept implies, to a large extent, a convention of the concept of "national economies" in connection with the inclusion of the latter in a ramified and truly global, all-terrestrial, all-planetary activity of transnational industrial and financial (banking) structures (TNCs); the informatization and the expansion of means of communication that have radically changed even the usual physical ideas of distances, space and time, made impossible the former national-state and cultural isolation, pulled people, countries and peoples together at arm's length "...

As we see, globalism means, firstly, some processes of socio-economic development, presented neutral in political and economic terms, creating an impression of phenomena no more than rational-economic, and, secondly, it is implicated that they are universal, planetary, in other words, global in nature. It is stressed that the implied processes are global in nature, that is, the linguistic sense of this concept is emphasized. "Globalism" - from "global", "something global": worldwide, universal, planet wide, overarching. "Globalism" is what embraces the global (and the process of embracing). "Global" - these are the above-mentioned processes of a socio-economic nature.

Approaches to the definition of globalization and the socio-economic essence of this phenomenon can be found in the works by domestic researchers A.N. Chumakov, I.A. Gobozov, K. Kh. Delokarov and others. Among the works of foreign authors, the most interesting is the article by W. Beck "What is Globalization?" and the work by Z. Bauman "Globalization. Consequences for Man and Society".

It is impossible to be limited only to this sense of the concept, however. Otherwise, it should be agreed that "globalism" is a decoy, a euphemism that was supposed to mask the socio-economic (political-economic) nature of the phenomenon. For globalism directly and immediately indicates only the scale of the processes that should supposedly characterize it - universal, that is, literally expresses its linguistic meaning, although this, of course, is not only a linguistic concept.

But such a familiar and relevant concept in socio-philosophical and scientific literature as "contemporary global problems" means something only when its content pushes the boundaries of commonplace - emphasizing that a number of problems (environmental, demographic, etc.) has acquired a worldwide, planetwide, and, threatening, problematic character in the literal sense.

However, without analyzing the socio-economic content of these problems, that is, without linking them to a certain type of society, their universality and their problematic nature appear to be unsupported and unsustained.

These "problems" have always been of local significance. But the corresponding societies have always found an advantageous and suitable way of escaping from the situation, mediated and conditioned by the tribal methods and mechanisms of their functioning.

However, with the advent of the New Time, these problematic situations slowly, but in their tendencies, gradually began to acquire an increasingly large-scale character, encompassing many diverse societies. At the same time, the character is problem-threatening. An indirect confirmation of this and a peculiar attempt to solve them is the Malthusian theory. In the 20th century, these problems are manifest in full vigor. 
These or those situations become "global problems", that is, they acquire planetary coverage and are really acute, threatening in nature only in connection with the general nature of those relations of society and those modes of production, those goals and priorities of socio-economic activity, within and in the framework of which they have arisen. In other words, the general and specific nature of the latter, that is, social relations, predetermines the global and problematic nature of the former (the problems that we classify as global). The nature of these relations in the essential sense has not changed in the context of classical political economy - the capitalist mode of production which determines all other parties, the goals and priorities of socio-economic activity and social life, all aspects of the production of life.

At the same time, ordinary sophisms are references to the involvement of all mankind into the global process, the change of the nature and priorities of production, the introduction of new technologies, etc. as to immediate cause of global problems. They are only indirect causes, and they themselves are the result of the development of capitalist production in the 20th century. "Involvement", "implementation", "change", etc. are different; their technical and technological sides have ambiguous consequences, giving it straight, not only the bourgeois-capitalist ones. The whole, its nature - the organism - transforms and mediates the processes that take place in it, which look different outside it.

Similarly, emphasizing in "globalism" only its "universality", thereby "neutrality" in political, economic or social terms, is scientifically unscrupulous. "Globalism" expresses quality. But quality is the internal certainty of an object which may be different depending on the relations in which the object (thing) is located. As Hegel noted, "this relation is the truth of any existence".

In "globalism" we can distinguish at least two qualities, internal and external, - one, internal, associated with the political, economic and social content of this concept, the other, external, expresses the totality of phenomena and processes being external, "visible", measured, represented in the forms of economic and social activity, mediated by the introduction of high technologies, etc. This, in addition to the transformations already mentioned in the field of economics, technologies, communications, etc., fundamentally reverses familiar attitudes and relationships, changes in the structure of the economy, social and professional structure of the population, standardization of educational programs, unification of needs, cultural and everyday needs, etc. When they talk about globalism (especially its ideological protectors), one purports most often this aspect of the matter, and the whole of "globalism" is reduced to it.

This completely obscures the fact that all these external manifestations of globalism (which, of course, have significant existential consequences, described below) can be mediated by different goals, have different social orientations and results. For example, one ignores even the simpl fact that knowledge is a value, a commodity, being objectified in the results of production activity; therefore, the relations and goals of production are determinative here. The connection between all these processes of "globalism" (if we talk about its socio-economic basis) with a certain type of production and social relations is obvious. And one can speak about "globalism" scientifically only taking into account this fundamental fact. The internal (socio-economic) basis of modern globalism, therefore, is predetermined by other, subordinate, aspects of the capitalist mode of production and the imperialistic nature of the claims of capitalism. Such is the connection between the internal and the external and the foundation of what to be called the "external manifestations" of "globalism" above

But, of course, by no means all these "external" manifestations (say, the widespread adoption of information technologies and means of communication, structural changes in the economy, education, etc.) are attributes of "globalism" and it is only represented, so to speak, by identifiers of "globalism". They, these manifestations, can occur on a different basis, not capitalist one, and, therefore, have other social consequences. Then they should not be considered in the context of "globalism", "globalism" is not determined by its technical or technological content only, this is a purely political and social and economic concept.

Modern globalism should be understood not just as the transition from closed national economies to an open one, but the capitalist and imperialist nature of these processes, therefore, primarily being subordinate to the goals, priorities and values of it, capitalism. All other goals, priorities and values are mediated by them and are sacrificed to them in case of conflict with them.

The essence of globalism is most frankly expressed in the activities of transnational industrial and banking corporations. But the political claims of globalism are organically connected with this, because its content should have an adequate form of its development through optimal and selfishly oriented political and state institutions, relations, politics, in other words, modern globalism is a multifaceted and multilevel complex phenomenon that can exist, only expanding and spreading its socio-economic essence, noted above, through political and other forms and techniques on a worldwide, planetwide level. 
However, not to notice the influence of these "external" "simply" technical and technological "global" changes on existential relations, on "changes in a person" means not to see the most disturbing in "globalism" (in the meaning of this concept indicated in a few lines above). And here we are already dealing with a different, metaphysical, aspect of the actual content of the concept of "globalism", which is a derivative of its meanings (therefore, supposing a preliminary review of them). This, seemingly, constitutes the actual socio-philosophical aspect of the problem of "globalism".

This is a vast difference between "man in the face of a global challenge" and, say, "man in a situation of globalism". The first, proceeding from a "politically and economically neutral" understanding of global changes, from their external, visible manifestations, implies, to put it more simply, the way how a person adapts to new conditions of life, which paths he chooses for this, what his life strategies consist of.

As a subject of study, this problem does not require an in-depth analysis of the nature of existing relations; it is enough to agree with the fact that they are perceived as an empirical reality, which one must reckon with, which one must adapt to and, if possible, use. This is mainly the subject of psychological and sociological research. In this case, they pay attention rather to global (external) changes in the world than to globalist ones (that is, expressing the socio-economic essence of globalism), since the former relate to all (therefore, everyone).

And here, how exactly they relate and what it entails is the globalist aspect of the problem, an analysis of the transformations of a person as a cultural-historical type in a situation of "globalism", because the latter, as if not to relate to it, is a fundamental fact and determining factor of time.

If we take only changes in programs and principles, the tendencies in reforming education, which we are witnessing, in the structure of culture, cultural requirements and needs, even in psychology, the mentality of "cultural figures", in the system of values, they, while maintaining current trends, cannot but lead to the formation of a "new man".

In fact, the man of every new historical era is a "new man" (say, a man of Antiquity, a man of the Middle Ages and a man of the New Time). When Plutarch in his Life Stories condemns Archimedes for engaging in engineering, that is, physical, "slavish" work, we don't understand this: other values, attitude to life, worldview, image of a person. Another man. But this is natural for the people of the world and the class of Archimedes. When enterprising mechanic Henry Ford becomes an ideal, a symbol and a hero, even the apotheosis of the era - these are also other values, priorities, a different image of a person. Another man. But this is natural for Ford's world and "planet".

It's all so, but the fact is that so far man has appropriated his essence in a universal way, through direct involvement in the cultural-historical, economic relations ("communication") of his environment, as well as relations with nature. This required (one way or another) his personal active and meaningful participation; he is not only a product of the environment, he is a creator, his needs and interests form a "type of environment". Education (not necessarily in educational institutions) and cultural space ("lower" and "upper") are such that they satisfy this paradigm of life. The carnival perception of the world or the "religious education" of a medieval man makes his worldview, his relations with the world, the community, his sense of life much richer than that of a person from the era of "globalism".

\section{Summary}

Interests and needs of globalism man are formed by "environment", and at the same time, the type of person who serves the interests of this Moloch of globalism, which can be saturated only by cloning such a "new man".

Czech cultural historian Jan Mukarzowski's exposition of the subject was very enlightening, "In the premachine era, a person used to react to reality with all his being, with all his needs ... used to react to all sides, all the properties of reality .... Machine takes control of reality very precisely .., but it can serve only one purpose ... Machine has become a model of a multifunctional creature that could serve only one clearly limited purpose, being at the same time needless in any other case. And man, being the creator and owner of the machine, adapts to this model." [8, p. 486]. Essentially, nothing changes here because the "machines" of the period of the information society are different. The essence is the same: man loses the "former fullness of his nature", becomes a function of a thing, an element in the functional interaction of things, it is required from him to develop one of his sides (a highly qualified, highly specialized worker), his needs (at the expense of others), most of all being corresponding to the function and logic of functionalism.

His thinking becomes so functionalistic. "Machine" of the information age only aggravates the state of affaires: man enters into pseudo-trusting, pseudo-personal relations with it - a mere aberration of reality occurs; the machine becomes his Virgil, he sees "using his eyes", listens to "using his ears", evaluates by his ratings.. 


\section{Conclusions}

The cultivation of the supersubstantial spiritual wealth of the masses is not the goal of any of the spheres of immaterial activity in the era of globalism: everywhere there are only the performance of functions and the consumption of digestible products, which only, in turn, reproduces their production.

The democratization of education in its bourgeois sense, that is, its commercialization, only fosters a commodity-money attitude towards the world, values, people, its place in life, only reproduces the "partial person", since education itself only becomes the preparation, processing for the optimal performance functions. There is a sharp narrowing (to the necessary minimum) of the space of education aimed at enriching the individual.

This is the vector of reformation of educational programs, regardless of its motivation. But this reform in the situation of modern globalism cannot have a different orientation objectively. The crisis of education about which there is much talk is a conflict between the former universalist paradigms of education and the needs of "globalism". The situation is exactly the same with respect to the structure and content of cultural requests, the nature of "spiritual food", the structure and nature of values, including material and everyday values.

This, of course, is only a typical expression of a trend (and only in one sphere). It, a tendency, is manifested with varying degrees of evidence and power. But this is a typical expression of the tendency of social development in the situation of modern "globalism". A metaphoric expression of the completion of this trend is the characters of dystopian novels.

\section{Acknowledgements}

The work is performed according to the Russian Government Program of Competitive Growth of Kazan Federal University

\section{References}

Bauman, Z. (2004). Globalization. Consequences for Man and Society. Ves' Mir.

Beck, W. (2001). What is Globalization? Progress-Tradition.

Brown, P., \& Loder, H. (2004). Education, Globalization and Economic Development. Sociology of Education: Theory, Research, Problems. Kazan: Kazan State University.

Chumakov, A. N. (2005). Globalization. The Contours of a Holistic World. Prospect.

Delokarov, K. K. (2005). Globalization as a Conceptual Problem. Russian Philosophical Congress (Vol. 3).

Gobozov, I. A. (2002). Globalization, Standardization and Show. Philosophy and Society, (3), 116-135.

Hegel, G. (1929). V. F. Works (Vol. 1).

Levy-Strauss, C. (2007). Mythology (Vol. 4). The man is Naked. Fluid.

Marx, K. (1959). Toward Criticism of Political Economy. F. Engels.

Mukarzhowsky, J. (1994). Research on Aesthetics and History of Art.

\section{Copyrights}

Copyright for this article is retained by the author(s), with first publication rights granted to the journal.

This is an open-access article distributed under the terms and conditions of the Creative Commons Attribution license (http://creativecommons.org/licenses/by/4.0/). 